\title{
Primo Levi jako instytucja. Rozważania na marginesie wizyt w Centro Internazionale di Studi Primo Levi w Turynie i Centro Culturale Primo Levi w Genui (z Tadeuszem Borowskim w tle)
}

\section{Wstęp: Levi i Borowski: podobieństwa, różnice, instytucje ${ }^{1}$}

„Dużo było książek o Oświęcimiu. [...] Nic lepszego od Tadeusza Borowskiego i od Primo Levi już się nie napisze”2 - mówiła Izoldzie R. Hania w Powieści dla Hollywoodu Hanny Krall. Przywołuję ten cytat na samym początku tekstu nie tylko jako usprawiedliwienie dla tytułowego zestawienia tak podobnych, a przy tym tak odmiennych pisarzy jak Primo Levi i Tadeusz Borowski, ale także ze względu na samo metonimizujące dyskusję nad literaturą Leviego i Borowskiego miejsce, w którym znalazła się ta paralela. Otóż pojawia się ona, po pierwsze, w książce, która ma co najmniej dwie, znacząco różniące się wersje (Powieść dla Hollywoodu była wydana później pod tytułem Król kier znów na wylocie), i która, po drugie, znacznie komplikuje układ referencji autor-narrator. I wreszcie, po trzecie, autorka tej książki to pisarka, która odmawia uznania się za pisarkę, reporterka jakoby tylko przekazująca to, co chcą powiedzieć inni - a która mimo to stała się swego rodzaju instytucją, ważnym punktem odniesienia w dyskusji wokół literatury Zagłady.

Dokładnie to samo powiedzieć można o Borowskim i Levim. Obaj przeformułowywali swoje świadectwa, w efekcie czego ich teksty funkcjonują w różnych, czasem diametralnie odmiennych wersjach. U obu też autobiograficzny narrator wykazuje niepokojące - szczególnie w kontekście wymagań stawianych literaturze świadczącej - rozbieżności między autorem i bohaterem³ ${ }^{3}$. Wreszcie obaj stali się $\mathrm{w}$ świecie i w Polsce swoistymi instytucjonalnymi punktami odniesienia, których

${ }^{1}$ Praca naukowa finansowana ze środków na naukę w latach 2009-2010 jako projekt badawczy. Opisywane dalej wizyty, które odbyłem kolejno: w dniach 21-23 XII 2009 r. w Turynie oraz 27-30 XII 2009 r. i 02 I 2010 r. w Genui, stanowiły część tego projektu.

${ }^{2}$ H. Krall, Powieść dla Hollywoodu [w:] eadem, Hipnoza, Warszawa 1989.

${ }^{3}$ Ta bardzo wyraźna u Borowskiego okoliczność zachodzi też w pisarstwie Leviego; polski czytelnik może natknąć się na nią już na początku lektury Czy to jest człowiek, tzn. w momencie rozbieżności między gniewną trawestacją Szma, modlitwą nakazującą wierność pamięci Izraela, a koncyliacyjnym, „pokojowym” projektem wpisanym we Wstęp. 
status świetnie obrazuje właśnie ów cytat z Powieści dla Hollywoodu: po Borowskim i Levim niczego nowego się już jakoby nie napisze, bo to ci dwaj - może nie jako jedyni, ale z pewnością jako jedni z najważniejszych - wyznaczają granice tego, co i jak można powiedzieć o Zagładzie. Miejsce, w którym pojawia się to zestawienie, rodzi więc w przywołanym przeze mnie kontekście instytucjonalnego wymiaru dyskusji wokół literatury Zagłady szereg pytań, spośród których większość krąży wokół takiej oto frapującej hierarchii: Levi posiada „własne” instytucje zrzeszające jego licznych komentatorów, Borowski ma komentatorów, nie ma zaś instytucji, a Krall nie ma instytucji (miałoby się jednak ochotę dodać: bo sama Krall jest swoistą instytucją), ale też rzadko stanowi, jak w przypadku Borowskiego, tło porównania, bo częściej jest osobnym obiektem komentarzy. Jeśli chodzi o wyizolowany z tej trójstopniowej hierarchii przypadek Borowskiego, to można chyba przypuścić, że taki jego obraz wynika z tego, że w Polsce brak właściwie „Borowskologii” - na tle wyraźnej we Włoszech „Leviologii” - a najnowsze komentarze do pisarstwa autora Pożegnania z Maria, na przykład autorstwa Sławomira Buryły, Dariusza Kuleszy czy Michała Januszkiewicza ${ }^{4}$, to paralelne zestawienia, w których Borowski występuje nie jako samodzielny obiekt rozważań, ale zaledwie jako element porównania. Borowski jest więc wprawdzie instytucjonalnym, ale przy tym raczej przyczynkowym, pozbawionym centralnego miejsca odnośnikiem. Wokół Hanny Krall natomiast, w odróżnieniu od Borowskiego, narósł w pewnej mierze autonomiczny dyskurs - ale podobnie jak Borowski, jej postać nie wygenerowała wyraźnego centrum instytucjonalnego. Nie ma więc tu żadnej osobnej organizacji, instytucji, działającej nie na zasadzie dyskursu, ale konkretnego zrzeszenia. Levi zaś nie tylko funkcjonuje we włoskim i światowym literaturoznawstwie - także pozaholokaustowym $^{5}$ - jako autonomiczny obiekt badań i komentarzy ${ }^{6}$, ale, co z tym

${ }^{4}$ Wyjątkiem jest książka Justyny Szczęsnej Tadeusz Borowski - poeta (Poznań 2001).

${ }^{5}$ Wymienić można na przykład niemałą bibliotekę prac analizujących pisarstwo Leviego z perspektywy językoznawczej, nieuwzględniającej (a w każdym razie nieujmującej jako zasobu faktów badawczych) kontekstu doświadczenia obozu: P.V. Mengaldo, Lingua e scrittura in Levi [w:] Primo Levi: Un'antologia della critica, red. E. Ferrero, Torino 1997; J. Nysted, Lunghezza della frase e interpunzione: mezzi stilistici in Primo Levi, „Studi Italiani di Linguistica Teorica e Applicata” 1992, nr 1-2; eadem, I forestierismi nel lessico di Primo Levi, „Italianistica scandinava. Atti del Terzo Congresso degli Italianisti Scandinavi” 1992; eadem, Le opere di Primo Levi viste al computer. Osservazioni stilolinguistiche, „Acta Universitatis Stockholmiensis” 1993; S. Bartezzaghi, Cosmichimiche, „Riga” 1997, nr 13.

${ }^{6}$ Wszystkich rozpraw poświęconych Leviemu nie sposób tu wymienić. Spośród najważniejszych warto wspomnieć o następujących publikacjach: M. Anissimov, Primo Levi: Tragedy of an Optimist, przeł. S. Cox, London 1988; Primo Levi as Writer and Witness, red. R.S. Kremer, New York 2001; Robert C.S. Gordon, Primo Levi's Ordinary Virtues. From Testimony to Ethics, Oxford 2001; Diffusione e conoscenza di Primo Levi nei paesi europei. Atti del convegno, Torino 9-10-11 ottobre 2003, red. G. Tesio, Torino 2005; F. Rastier, Ulysse à Auschwitz. Primo Levi, le survivant, Paris 2005; A. Minisci, Primo Levi e la memoria della Shoah, Milano 2006; E. Ferrero, Primo Levi. La vita, le opere, Torino 2007; Ph. Mesnard, Primo Levi. Una vita per immagini, przeł. F. Sessi, Venezia 2008. 
zapewne związane, dał ponadto imię instytucjom we właściwym znaczeniu tego słowa. Czy ta nierówna sytuacja - odnoszę się do paraleli Borowski-Levi, zarysowanej przez narratorkę Krall (pomijam tymczasem dalsze pytania o rolę Krall w tym układzie; jest to sprawa domagająca się rozpatrzenia przy innej okazji) może i czy powinna ulec zmianie? Jeśli tak, to w jaki sposób? W niniejszym tekście postaram się odpowiedzieć na te pytania, choć w odwrotnej kolejności: najpierw pokażę, jak przebiega instytucjonalizacja postaci i pisarstwa Leviego we Włoszech, odwołując się w tym celu do odwiedzonych przeze mnie w grudniu 2009 i styczniu 2010 roku instytucji jego imienia, potem zaś wskażę na sposób tworzenia opowieści o literaturze Zagłady w tak ważnym medium instytucjonalnym, jakim jest rekomendowany przez Unię Europejską podręcznik europejskiej literatury; robiąc to, postaram się wskazać jedną z możliwych odpowiedzi na pytanie o kierunki instytucjonalnego rozwoju figury Borowskiego i innych pisarzy literatury Zagłady w Polsce oraz spróbuję zarysować projekt wobec niego alternatywny.

\section{Primo Levi jako instytucja}

Dwie z trzech istniejących instytucji imienia Leviego znajdują się we Włoszech w Genui i w Turynie, trzecia zaś w Nowym Jorku. Tę ostatnią pomijam tymczasem z trzech względów: po pierwsze, staram się ukazać formowanie się instytucji literatury Zagłady jako swoistego literackiego i literaturoznawczego obszaru, co w sposób spójny przeprowadzić można tylko wtedy, gdy ukazuje się funkcjonowanie tego zjawiska w jednolitych warunkach. Amerykańska dyskusja wokół tej literatury - to jednocześnie drugi powód pominięcia - choć istotnie wpływa na kształt całej deba$t^{7}$, to jednak toczy się w innych warunkach i jako taka domaga się osobnego rozpatrzenia $^{8}$. Wreszcie, po trzecie, jednolitość obrazu instytucjonalnej dyskusji wokół Leviego mogłaby zostać zakłócona przez fakt, że status jej włoskich konkretyzacji jest mi znany bliżej (z rozmów z pracownikami i drobnej współpracy w pomniej-

${ }^{7}$ Przy innej okazji broniłem tezy ustalonej już właściwie przez badaczy - takich jak Berel Lang (Nazistowskie ludobójstwo. Akt i idea, przeł. A. Ziębińska-Witek, Lublin 2006, s. 23), David Roskies (Czym jest literatura Holokaustu?, przeł. M. Adamczyk-Garbowska, „Literatura na Świecie” 2005, nr 9-10, s. 225), Tomasz Majewski (Dyskurs publiczny po Shoah, [w:] Pamięć Shoah. Kulturowe reprezentacje i praktyki upamiętniania, red. T. Majewski, A. Zeidler-Janiszewska, współpraca red. M. Wójcik, Łódź 2009, s. 237-238) i inni że zarówno dzisiejsza literatura, jak i samo pojęcie Holokaustu ma właściwie swoje źródło w USA.

${ }^{8}$ To zresztą na tyle istotny z punktu widzenia moich zainteresowań temat, że zamierzam się nim zająć bliżej, gdy tylko nadarzy się odpowiednia możliwość; odbyłem już zresztą w tej sprawie wstępne rozmowy z Alessandrem di Rocco, przedstawicielem nowojorskiego Centro Primo Levi (http://www.primolevicenter.org/Home.html). Jest ono afiliowane przy omawianym przeze mnie w dalszej części centrum genueńskim, ale działa w warunkach na tyle odmiennych i stawia sobie na tyle odmienne cele, że niemożliwe byłoby rozpatrywanie jego działalności tak, jakby była częścią funkcjonowania instytucji genueńskiej. 
szych obszarach ich działalności), a informacje o funkcjonowaniu centrum w Nowym Jorku mogłem zaczerpnąć jedynie ze strony internetowej oraz - telefonicznie od jego przedstawiciela.

\subsection{Centro Internazionale di Studi Primo Levi}

Oba omawiane przeze mnie centra znajdują się w nieodległych od siebie, ale diametralnie różnych miastach. Wyrazem różnicy między Turynem i Genuą uczynić by można ich architekturę - turyńską logiczną i przejrzystą strukturę, opierającą się na układzie prostopadłych, szerokich ulic i powikłaną plątaninę mrocznych genueńskich caruggi, czyli małych uliczek. Podobnie rysuje się różnica między działalnością centrów turyńskiego i genueńskiego: to pierwsze obrało wyraźny cel, do którego prowadzi za pomocą konwencjonalnych naukowych narzędzi, to drugie zaś operuje na tak wielu płaszczyznach i w tak wielu kierunkach prowadzi swoją działalność, że tworzą one bogatą mozaikę niejednakowych linii rozwoju. W dalszej części tekstu będę starał się wyjaśnić bliżej tę urbanistyczną metaforę.

Statut Centro Internazionale di Studi Primo Levi (Międzynarodowego Centrum Badań nad Primo Levim) powstał w kwietniu 2008 roku, ale rzeczywiste otwarcie instytucji nastąpiło dopiero w grudniu roku 2009. W krótkim okresie dotychczasowej działalności Centrum zdołało wypełnić większość statutowych zamierzeń, które koncentrują się przede wszystkim wokół tak oto określonego celu: „stworzenie kompletnego centrum informacyjnego i dokumentacyjnego o Primo Levim i jego dziełach poprzez opracowanie pełnego spisu źródeł oraz archiwum opracowań, publikacji, prac dyplomowych, dokumentów archiwalnych, świadectw" ${ }^{\prime \prime}$. Ten sam statut wymienia jeszcze takie obszary aktywności, jak działalność dydaktyczna czy utworzenie strony internetowej mającej stanowić medium pośredniczące i ułatwiające badania nad Levim. I rzeczywiście: w bazie internetowej Centrum znaleźć można nie tylko odsyłacze do związanych z Levim archiwów innych instytucji (linki i opis ich zawartości), ale także wiele zeskanowanych tekstów i dokumentów oraz wykaz przekładów książek Leviego (informacje o polskich wydaniach zawierają niewielkie nieścisłości, które niedługo zostaną poprawione). Jest tam ponadto wciąż uzupełniana bibliografia pism autora Czy to jest człowiek, ich opracowań, artykułów o pisarzu i wszelkich opublikowanych materiałów, która dodatkowo została uporządkowana wedługnajwyższych bibliograficznych standardów.Znaleźćwniej można słowa klucze takie jak „Zwierzęta” - temat ważny szczególnie z punktu widzenia „opowiadań fantabiologicznych” pisarza, „Sen”, „Szara strefa” czy dwa duże zespoły haseł: „Recepcja”, z odnośnikami do trzydziestu obszarów językowych, i „Intertekstualność”, z odnośnikami do odpowiednich tekstów lub autorów - np. „Biblia” albo „Tadeusz Borowski”. Ta baza źródeł do badań nad Primo Levim połączona jest dodatkowo $\mathrm{z}$ bazą biblioteki Istoreto, czyli Istituto piemontese per la storia

${ }^{9}$ Costituito il Centro Studi Primo Levi, tekst dostępny na stronie http://www.compagniadisanpaolo.it/file/pdf/9_CS_090408_161.pdf, data ostatnich odwiedzin: 27 III 2010. 
della Resistenza e della società contemporanea (Piemonckiego instytutu historii ruchu oporu i społeczeństwa współczesnego), zajmującego się między innymi losami Żydów włoskich podczas II wojny światowej i gromadzącego zbiory biblioteczne dotyczące tego tematu. Dyrektorem Centro Internazionale di Studi Primo Levi jest Fabio Levi ${ }^{10}$ (niespokrewniony z pisarzem; mimo to, opisując inaugurację Centrum, włoska prasa - jak z rozbawieniem zaznacza sam zainteresowany - nie omieszkała ogłosić otwarcia instytucji kierowanej jakoby przez syna pisarza), który jest jednocześnie wykładowcą na Uniwersytecie Turyńskim; być może więc także stąd, a nie tylko ze statutowego obowiązku, to naukowe w zasadzie centrum prowadzi również działalność dydaktyczną. Pod kierunkiem profesora Fabia Leviego powstaja bowiem przynajmniej dwie prace dotyczące szkolnych wydań Czy to jest człowiek ${ }^{11}$, a ponadto Centro Internazionale di Studi Primo Levi organizuje cykl lekcji kierowanych przede wszystkim do uczniów szkół podstawowych i ponadpodstawowych. Pierwsza z nich została przeprowadzona 10 października 2009 roku przez oksfordzkiego badacza pisarstwa Leviego, Roberta Gordona (temat kolejnych nie został jeszcze ustalony; wykłady zostaną opublikowane w wydawnictwie Einaudi). Centrum gromadzi także fotografie i obrazy związane z pisarzem (notabene: dotychczas zorganizowano niejedną wystawę fotografii i grafik Leviego i o Levim - np. Primo Levi. I giorni e le opere ${ }^{12}$, ale niewiele znaleźć można książek poświęconych temu skądinąd ciekawemu tematowi ${ }^{13}$ ), organizuje konferencje i wystawy. Fabio Levi z duma oświadcza, że Centrum zebrało już ponad 2000 elementów zbioru archiwalnego, to jest książek i tekstów, które fizycznie znajdują się w bibliotece instytucji. Zaznacza jednocześnie, że działalność Centrum znajduje się dopiero na początku rozwoju i że

${ }^{10}$ Inni członkowie Rady Międzynarodowego Centrum Badań nad Primo Levim [Il Consiglio di Amministrazione del Centro Studi Primo Levi] to: Bianca Guidetti Serra, Amos Luzzatto, Ernesto Ferrero, Fiorenzo Alfieri, Dario Disegni, Valter Giuliano, Tullio Levi.

11 Jedna właściwie została już ukończona. Tę też czytałem, obrona drugiej odbędzie się prawdopodobnie roku akademickim 2010/2011 lub 2011/2012. Wspominam o tym na pozór mało ważnym fakcie, bowiem temat obecności Leviego i Borowskiego w nauczaniu szkolnym jest niedoinwestowanym obszarem badawczym, podobnie jak - choć w mniejszym stopniu - temat szkolnego nauczania o literaturze Holokaustu (w odróżnieniu od nauczania o Holokauście jako zdarzeniu); uważam, że warto się nimi w najbliższej przyszłości zająć.

${ }^{12}$ Primo Levi. I giorni e le opere. Prodotta dal Centre d'Histoire de la Resistance et de la Déportation della città di Lione e presentata a Torino dal Museo Diffuso della Resistenza della Deportazione, della Guerra dei Diritti e della Libertà, dal 18 aprile al 14 marzo 2007 con il sostegno della Regione Piemonte e della Città di Torino e la collaborazione della Fondazione Teatro Stabile di Torino. Tekst zamieszczony na stronie: http://www.istoreto.it/didattica/2701_PrimoLeviGiorniOpere/, data ostatniej wizyty: 21 III 2010.

${ }^{13}$ Wyjątkiem jest praca francuskiego komentatora pism Leviego Philippe’a Mesnarda (op. cit.). Jest to temat ciekawy między innymi dlatego, że Levi w pewnym momencie zainteresował się grafiką komputerową, i to w momencie ważnym, bo wtedy, gdy zaczął pisać swe teksty na komputerze; gdzie indziej bronię tezy, że sposób zapisu zmieniał też jego sposób opisu doświadczenia. 
zostało jeszcze wiele do zrobienia: w nieopracowanym jeszcze archiwum, czyli, między innymi, we wciąż zamkniętych w kartonach zbiorach ofiarowanych przez Gabrielę Poli, spoczywa prawdopodobnie ta część korespondencji Leviego, która nie dysponuje rodzina (co daje badaczom Leviego nadzieję na otrzymanie niedostępnego dotąd właściwie, a jakże ważnego obszaru literatury świadectwa Leviego: epistolografiii ${ }^{14}$ ). Fabio Levi zwraca też uwagę na fakt, że unieruchamiająca dyskusję centralizacja badań nad Levim nie jest zasadniczym celem jego instytucji: „Kontakt czytelników z Primo Levim to zjawisko szczególne, które rozciąga się na okres następujący długo po śmierci pisarza. Naszym celem jest ułatwiać ten kontakt; chcemy być pośrednikiem w relacjach czytelników z Levim”. I dodaje: „W naszym pośrednictwie nie chcemy zbytnio skłaniać się w żadną ze stron: ani Primo Leviego, ani jego czytelników”, mając zapewne na myśli to, że Centrum nie zamierza być ani jedynie muzeum, ani tylko czytelnią. Nie tylko ta wypowiedź każe myśleć o owej instytucji jako o miejscu nie tyle reprodukcji literatury Leviego, ile jej produkcji, kreacji (bo jeśli nie chodzi o biblioteczną archiwizację tekstów ani o muzealne konserwowanie pamięci - to być może chodzi o kształtowanie dyskusji wokół nich?). Świadczy o tym także pewien pozornie przypadkowy i nieważny fakt. Otóż biblioteka Centro Internazionale di Studi Primo Levi łączy się z czytelnią wspomnianego wcześniej Istoreto, ale w katalogu żadnej z nich Holokaust nie jest najbardziej eksponowanym elementem wiedzy o Levim. Wśród rzeczowych haseł bibliograficznych Zagłada stanowi tylko jeden z odnośników, a na stronie głównej internetowego portalu instytucji, na której umieszczono promieniście rozlokowane odnośniki do poszczególnych działów (takich jak „Biografia”, „Nauka”, „Auschwitz”), Holokaust wcale nie zajmuje centralnego miejsca. Wszystkie te odnośniki koncentrują się bowiem na umieszczonym w środku linku zatytułowanym „Dzieła”. I tak właśnie zdaje się wyglądać owa pośrednicząca działalność Centrum: tekst, literatura jest najważniejszym elementem, z niego dopiero wynikają wszystkie pozostałe obszary zainteresowania. Potwierdza to zresztą jeszcze jeden niemal niezauważalny fakt: odnośnik, pod którym znaleźć można informacje na temat żydowskiej tożsamości pisarza, został nazwany „Argon”. Argon to tytuł opowiadania z niewydanego w Pol-

${ }^{14}$ Dotychczas, w odróżnieniu od źródeł do badania pisarstwa Borowskiego, wśród których znaleźć można jego korespondencję opracowaną przez Tadeusza Drewnowskiego (Niedyskrecje pocztowe. Korespondencja Tadeusza Borowskiego, zebrał, objaśnił, skomentował T. Drewnowski, Warszawa 2001), jedynym opublikowanym materiałem epistolograficznym w badaniach nad Primo Levim jest - otwierająca o wiele mniej możliwości badawczych niż Niedyskrecje... - książka Lucii Veneri Nić Ariadny. Ja i Primo Levi (L. Veneri, Il filo di Arianna. Io e Primo Levi, Milano 2005), w której autorka opisuje swoją korespondencję z pisarzem. Źródłem ograniczającym się, podobnie jak książka Veneri, do pewnego obszaru korespondencji pisarza (i jego rodziny), są zbiory Archiwum historycznego domu wydawniczego Giulio Einaudi (1933-1983) [Archivio storico della casa editrice Giulio Einaudi Editore (1933-1983)], które stanowi część Archiwum Państwowego w Turynie [Archivio di Stato di Torino]; można w nim jednak znaleźć pewne wątki warte skomentowania (co zamierzam przy najbliższej okazji uczynić). 
sce Układu pierwiastków ${ }^{15}$, w którym autobiograficzny narrator opisuje dzieje swoich żydowsko-piemonckich przodków. Jest to tym samym jedyny link nazwany tytułem zaczerpniętym z pisarstwa Leviego; jednym zdaniem: tożsamość żydowska pisarza jest na oficjalnej stronie Centrum - jako jedyna - kryptonimowana literaturą. Fabio Levi tak oto tłumaczy tę decyzję: „Potrzebowaliśmy nazw krótkich, bo tego właśnie wymaga się od wpisów na stronie internetowej. Krótkich i trafiających w sedno” - i dodaje, że nie tylko ten odnośnik, ale także łącze z informacjami o edukacyjnym wymiarze dzieł Leviego zostało nazwane tytułem jego tekstu: „Do młodych - bo tak brzmi tytuł tego linku - to przecież tytuł posłowia dołączonego przez autora do jednego z wydań Czy to jest człowiek”. Nie zmienia to jednak faktu, że ów zabieg komponuje się w spójny obraz Leviego przede wszystkim - czy nawet wyłącznie - jako pisarza, oddanego czytelnikom bez dodatkowych kwalifikatorów, takich jak „holokaustowy” lub „żydowski”. Jedno i drugie, doświadczenie Zagłady i żydowska tożsamość, staje się tu zatem wymiarem tekstu, a nie odwrotnie - tekst funkcją zdarzenia Auschwitz. Wynika to prawdopodobnie z zamierzenia, w którym oprócz przywoływanych już przeze mnie słów Fabia Leviego o tym, że Centrum chce zająć pośrednie miejsce między Levim a jego czytelnikami, uwzględnia się także i to - znów cytuję dyrektora Centrum - że „relacje czytelników z Levim to rzecz bardzo intymna” i w związku z tym jego organizacja otwiera się na rozmaite lektury, także takie, które nie poszukują w tekście Leviego przede wszystkim opowieści o Holokauście. A jednocześnie kontekst drugiej wojny i tożsamości żydowskiej jest w działalności Centrum oczywisty, chociażby poprzez lokalizacyjną - acz nie administracyjną (co dyrektor Centrum silnie podkreśla) - afiliację z Istoreto. Jest to bowiem instytucja, która choć zajmuje się głównie wojennymi i powojennymi losami włoskich Żydów, to w nazwie eksponuje przede wszystkim określenie „ruch oporu” (Piemoncki instytut historii ruchu oporu i społeczeństwa współczesnego) i tym samym wyraźnie określa się jako instytucja ocalającą niemartyrologiczną pamięć o Żydach. Kontekst ten ujawnia się też za pośrednictwem pewnych sygnałów, które - zamierzenie lub nie - sugerują, że tekstu Leviego nie można odłączyć od żydowskiej kultury i jej powojennych przekształceń, w tym jej najnowszych etapów.

\subsection{Centro Culturale Primo Levi}

Nieco inaczej jest w przypadku genueńskiego Centrum Kulturalnego Primo Leviego (Centro Culturale Primo Levi), które wyraźnie i deklaratywnie zajmuje się przede wszystkim szeroko rozumianą tożsamością i kulturą żydowską. Jednak i w przypadku tego centrum Holokaust nie jest najważniejszym elementem zainteresowań. Właściwie Holokaust - przynajmniej na gruncie deklaracji składanych przez przedstawiciela tej organizacji - nie obchodzi jej prawie wcale. „Naszym celem jest mówić jak najmniej o Szoa” - mówi jej przewodniczący Pietro dello Strologo. Jeszcze bardziej niż w przypadku poprzednio omawianej instytucji na-

\footnotetext{
${ }^{15}$ P. Levi, Il sistema periodico, Torino 1975.
} 
rzuca się w związku z tym pytanie: jak pogodzić ten zamiar z faktem, że patron Centrum, Primo Levi, w każdym właściwie tekście w ten czy inny sposób pisał o Holokauście ${ }^{16}$ ? Jak z niezmierzonego Leviańskiego pantekstu wydobyć takiego Leviego, który nie mówi o Auschwitz?

Tak oto odpowiada na to pytanie cytowany przed chwilą przedstawiciel Centro Culturale Primo Levi: „Centrum nie zajmuje się w szczególności Primo Levim. Powstało po to, żeby ukazać światu wartości, jakie wniosła weń kultura żydowska”. Statut Centrum precyzuje to następująco: „Celem Centrum Kulturalnego Primo Leviego jest promocja i wprowadzanie w życie inicjatyw kulturalnych, wydawniczych i społecznych, mających za zadanie badać i upowszechniać kulturę żydowską we wszelkich jej aspektach”17. W związku z tym, mimo że działalność instytucji zainaugurował panel zatytułowany Primo Levi - wspomnienie, z udziałem między innymi znanego komentatora prac pisarza Cesare Casesa (11 kwietnia 1991 roku), i mimo faktu, że ważnym aspektem działalności instytucji jest przyznawanie nagród imienia pisarza tym, którzy - mówiąc słowami przewodniczącego Centrum „podążali śladem Primo Leviego"18, to wszystkie kolejne wydarzenia miały niewiele wspólnego zarówno z pisarzem, jak i z tematem Zagłady: Centrum organizowało później na przykład Lekcje na temat historii wspótczesnego żydostwa (w latach 1992-1993), wykłady na temat dziesięciu przykazań (w latach 1995-1996), konferencję zatytułowaną Bruno Schulz: pisarstwo i tożsamość żydowska (luty 2001) a więc imprezy, które nie odwołują się wprost do Holokaustu. Nawet jeśli w ramach działalności Centrum podejmowane są jednak wątki Zagłady, to raczej wyjątkowo i zazwyczaj w kooperacji z innymi organizacjami, a nie jako autonomiczne przedsięwzięcia tej instytucji. Przykładem może być Dzień pamięci z 27 stycznia 2008 roku, który organizowało wraz z Centrum trzynaście innych instytucji. Cytowany już przewodniczący i założyciel Centro Culturale Primo Levi wyjaśnia, skąd ta trudna (ale nie niemożliwa) do uzgodnienia ze skojarzeniem, jakie budzi Levi, natura przedsięwzięć genueńskiej organizacji: „Wojnę przeżyłem w Szwajcarii; po wojnie, we Włoszech, ja i moja rodzina doświadczaliśmy wprawdzie aktów antysemityzmu, ale nie o tym chcę mówić, nie chcę dać się poznać jako poszkodowany. Żydzi stanowili spoiwo XX wieku i na tym skupia się właśnie cel mój i Centrum: pokazać pierwiastek żydowski - a szczególnie żydostwa włoskiego - w kulturze dwudziestowiecznej. Także dlatego, że obecnie włoska kultura żydowska uległa rozproszeniu”. Taki sposób (nie)mówienia o Holokauście da się zresztą wyczytać

${ }^{16} \mathrm{Z}$ niewieloma wyjątkami; można za takie uznać większość opowiadań fantastycznych czy „powieść rzemieślniczą” - La chiave a stella, czyli „Klucz monterski”; w innym miejscu staram się jednak uzasadnić tezę, że kontekst Zagłady jest i tym tekstom nie tylko narzucany $\mathrm{w}$ recepcji, ale w pewnej mierze także zaprojektowany przez autora.

${ }^{17}$ Statut Centrum Kulturalnego Primo Leviego z 13 stycznia 1990, dostępny na stronie internetowej Centrum (adres podany na końcu niniejszego artykułu).

${ }^{18}$ Pierwszą otrzymał Elie Wiesel, po nim byli m.in. Willy Brandt, który nie dożył jej wręczenia, Steven Spielberg, organizacja „Médecins Sans Frontières”, z Polaków zaś Olek Mincer. 
z pisarstwa Leviego (jeśli, na przykład, wziąć za dobrą monetę jego przedmowę do niemieckiego wydania $C z y$ to jest człowiek $^{19}$ ), ale nie to jest chyba w uzasadnieniu wyboru takiego, a nie innego patrona najważniejsze. W działalności Centrum nie chodzi bowiem najwyraźniej o to, co mówił Primo Levi, ale o to, jak jest czytany, albo raczej jak może być czytany dziś, i co dziś znaczy dla kultury żydowskiej, europejskiej i światowej. Prezes Centrum tak to ujmuje: „Dziś Primo Levi stanowi bardzo silnie oddziałujący obraz, mogący być pomocnym wehikułem ważnych zagadnień i umożliwiający tym samym zjednoczenie ośmiuset osób [mowa o przybliżonej liczbie osób zrzeszonych członkostwem w Centrum - P. W.], które właśnie te zagadnienia starają się poruszać".

Otóż w pewnym sensie owo niemówienie o Zagładzie dokonywane za pośrednictwem szeroko znanego włoskiego pisarza Zagłady, stanowi, paradoksalnie, bardzo aktualny sposób mówienia o niej. Prezes genueńskiego Centrum, tak silnie podkreślając niewiktymizujący styl mówienia o kulturze żydowskiej, w pewnym sensie podejmuje nurt sygnowany we Włoszech publikacjami takimi jak Racconti della Resistenza ${ }^{20}$, w których Primo Levi pojawia się jako autor mało znanego opowiadania Morte del Marinese, opowieści wcale nie obozowej, ale partyzanckiej, heroicznej, w Polsce zaś na przykład przedsięwzięciami wydawniczymi takimi jak książka Żydzi w walce ${ }^{21}$, która dokonuje rewizji obrazu Żydów jako bezwolnych ofiar, jako jedynie więźniów gett i ofiar. Nie chodzi mi o to, że jest to świadomy projekt przewodniczącego Centrum (bo ten zawiera się raczej w integracji - w tym w dużej mierze polityczno-społecznej - środowiska włoskich Żydów), ale że komponując się z aktualnymi nurtami dyskursu Zagłady, współtworzy go nawet wówczas, gdy na poziomie deklaratywnym od takiego celu stara się dystansować.

\section{Podsumowanie: Levi, Borowski i instytucje. Sprawa polska}

Wstępny wniosek z powyższych rozważań mógłby brzmieć tak: Primo Levi, gdy staje się elementem struktury zinstytucjonalizowanej, może posłużyć za wehikuł różnych zamierzeń i kierunków działalności, a jednak ostatecznie i tak staje się znacznikiem dyskusji wokół literatury i doświadczenia Zagłady. Dzieje się tak nie tylko wtedy, gdy - jak w centrum turyńskim - w punkcie wyjściowym ma być po prostu włoskim pisarzem, ale ostatecznie staje się jednak przede wszystkim tekstową figurą Holokaustu (między innymi w efekcie nazwania jednego z linków Argon, czyli tytułem opowiadania o żydowskich przodkach Leviego i jednocześnie o „ulotnym gazie”). Ma to miejsce także wówczas, gdy mając służyć za wehikuł dyskusji o kulturze żydowskiej w ogóle i jej przenikaniu się z kulturą światową, w istocie

\footnotetext{
${ }^{19}$ Mimo że Levi wspomina w nim o obozowym numerze, to poza tą pojedynczą wzmianką stara się przekonać czytelnika/tłumacza (tekst ma formę listu do autora przekładu), że napisał tę książkę nie tyle po to, by mówić o Zagładzie, ile by zrozumieć Niemców (P. Levi, Opere I, red. M. Belpoliti, wstęp D. Del Giudice, Torino 1997, s. 1136-1137).

${ }^{20}$ Racconti della Resistenza, red. G. Pedullà, Torino 2005.

${ }^{21} \dot{Z} y d z i$ w walce 1939-1945, t. 1, red. J. Diatłowicki, Warszawa 2009.
} 
przenosi ów wątek w obręb najbardziej aktualnego stylu mówienia o Zagładzie - jak w przypadku centrum genueńskiego. Chciałoby się w tym kontekście tak oto sparafrazować Krall: dużo jest książek i instytucji zajmujących się Primo Levim, ale na skutek współdziałania jednych z drugimi (to znaczy lektur z instytucjonalizacja) nic nieholokaustowego o Primo Levim się już nie napisze. Oczywiście nie musi być to prawda, a nawet może byłoby lepiej, gdyby to prawdą nie było (choć trudno znaleźć empiryczne dane, które miałyby takiemu stanowi rzeczy zaprzeczyć), ale z punktu widzenia niniejszego tekstu o wiele istotniejsza jest całkiem inna, choć też zainspirowana cytatem z Krall kwestia: jak do tego wszystkiego ma się Borowski i, w związku z tym, sytuacja polskiej (instytucjonalnej) dyskusji o literaturze Zagłady?

Zanim spróbuję odpowiedzieć na to pytanie, powinienem zastanowić się, jak już dziś wygląda instytucjonalny status Borowskiego. Jak wspomniałem na początku, nie można mówić tu o osobnej, autonomicznej organizacji zajmującej się pisarzem lub choćby przyjmującej jego imię. Z drugiej strony, na rozważenie takiego instytucjonalnego wymiaru dyskusji o pisarstwie Borowskiego, jakim jest jego obecność w programach nauczania szkolnego i akademickiego, w niniejszym tekście brak miejsca. Warto ją jednak przy innej okazji podjać, i to zarówno w odniesieniu do polskiego, jak i włoskiego pisarza. Pomijam więc te aspekty instytucjonalizacji figury Borowskiego, ale przywołam inny, wobec tamtych komplementarny: otóż Borowski ostatecznie stał się jednak elementem swoistej instytucji, którą jest kanon literatury europejskiej.

Mam na myśli wydaną przez ośrodek francuski, ale redagowaną przez literaturoznawców z różnych krajów Literaturę Europy ${ }^{22}$. Przedstawicielem literatury obozowej $^{23}$ (którą należy traktować jako odpowiednik nieobecnej pod tymi nazwami literatury Zagłady/Holokaustu/Szoa) jest w niej właśnie Tadeusz Borowski. Nie jest to jednak ten sam Borowski, którego znamy z rozpraw Wernera, Drewnowskiego, Buryły czy Szczęsnej. Istota obozowego pisarstwa tego „europejskiego” Borowskiego ma bowiem polegać na tym, że „paranoja moralna świata obozowego rządziła się własnymi regułami, których nie zrozumie nikt, kto nie przeżył obozu”24, na dowód czego redaktorzy przytaczają fragment z U nas, w Auschwitzu..., w którym narrator mówi o utylitarnym traktowaniu i maksymalnym wykorzystaniu ludzkiego ciała w obozie. A przecież Borowski, którego znamy, to nie autor U nas, w Auschwitzu..., najbardziej, jak wskazywali badacze ${ }^{25}$, nietypowego tekstu w jego pisarstwie, ale ra-

${ }^{22}$ Literatura Europy. Historia literatury europejskiej, red. A. Benoit-Dusausoy, G. Fontaine (red. naukowy wyd. pol.: M. Cieński), Gdańsk 2009.

${ }^{23}$ Trzeba jednak doprecyzować: literatury polskiej i dotyczącej obozów niemieckich. Literaturę rosyjskich łagrów reprezentuje bowiem Grudziński, natomiast doświadczenie żydowskie obozów koncentracyjnych w Niemczech i na okupowanych przez Niemców ziemiach Norbert Frýd i Arnošt Lustig (ibidem, s. 823).

${ }^{24}$ Ibidem, s. 823.

${ }^{25}$ Między innymi: A. Mencwel, Borowski albo dramat absolutyzmu moralnego [w:] idem, Sprawa sensu. Szkice, Warszawa 1971, s. 157; S. Buryła, Prawda mitu i literatury. O pisarstwie Tadeusza Borowskiego i Leopolda Buczkowskiego, Kraków 2003, s. 194. 
czej ten z Proszę państwa do gazu. To ten, który zgadza się z poglądem, że bycie bitym i w związku z tym bicie tych, którzy znajdują się niżej w obozowej/społecznej hierarchii, „to normalne, przewidziane i obliczone”26. W dodatku - co ważniejsze temu Borowskiemu, którego znamy, obca jest przecież jakakolwiek teza o „paranoi moralnej świata obozowego”. Przeciwnie: chce on pokazać, że obóz został stworzony przez ten sam świat, który wykształcił tak „moralnie nieparanoiczne” zjawiska jak muzyka, kultura, muzea i egipskie piramidy, i że wykorzystanie ciała to tylko konsekwentne stosowanie reguł ekonomii. Jak to możliwe, że Borowski, który pojawia się na kartach Literatury Europy, to Borowski niemający nic wspólnego z ukształtowaną w polskim literaturoznawstwie figurą pisarza - głosiciel zasadniczego dobra istoty ludzkiej? Otóż ten obcy, nieznany nam Borowski jest niezbędny z punktu widzenia projektowanego w tej publikacji literackiego odpowiednika europejskiej unii (projekt takiej instytucji wyraźnie wyłania się z Przedmowy Vairy Viķe-Freibergi), której potrzebna jest wizja wojny i Zagłady jako rozłamu jedności, a nie jako całkiem zwyczajnej apokalipsy. Jest to Borowski, którego nie tyle trudno, ile po prostu nie da się wyczytać z tekstu w toku kompetentnej lektury.

Ale jest to jednocześnie taki Borowski, który ma największe szanse - także za pośrednictwem omówionej tu pokrótce sytuacji quasi-instytucjonalnej - stać się punktem odniesienia dla celów niebaczących na spójność interpretacji jego tekstów, lecz dążących do stworzenia spójności doraźnej. Instytucja w twardym, organizacyjnym znaczeniu jest więc Borowskiemu potrzebna - niekoniecznie pod postacią organizacji jego imienia lub imienia jakiegokolwiek pisarza w ogóle - właśnie po to, żeby nie stał się własnością narracji, która wtłacza go w porządek chybiony z punktu widzenia intencji jego tekstu. Nie mam przy tym na myśli instytucji naukowych zajmujących się literaturą Zagłady w ogóle, bo te działają z powodzeniem i z powodzeniem przeciwdziałają podobnym tendencjom w odniesieniu do literatury Holokaustu w szerszym rozumieniu. Mam na myśli dyskurs instytucjonalny, którego przełożeniem może być organizacja w sensie administracyjnym, ale który przede wszystkim, zachowując status instytucji naukowej, wykraczałby jednak poza dyskurs profesjonalny, przełamując jego hermetyczność przy zachowaniu standardów analitycznej i interpretacyjnej kompetencji. Innymi słowy: nie chodzi o postulat stworzenia jakiejś quasi-policyjnej formacji strzegącej właściwej wykładni pism Borowskiego czy Leviego, ale o instancję dyskursywną stanowiącą instytucjonalny bufor dyskusji wokół tych - między innymi - pism. Podobnie działa przecież pośredniczące między ośrodkami akademickimi i szkolnymi, czytelnikami i pisarzem/pisarzami centrum turyńskie czy genueńskie centrum Leviego, występujące z pozycji judaistycznej myśli oświeceniowej, ale we współpracy z ośrodkami akademickimi, miejskimi i politycznymi. Polskie centrum Leviego, gdyby zostało utworzone w najbliższym czasie, mogłoby z powodzeniem wypełnić analogiczną, w przypadku Borowskiego dziś już trudną (ale nie niemożliwą) do uzupełnienia

${ }^{26}$ T. Borowski, Pisma w czterech tomach, red. T. Drewnowski, J. Szczęsna, S. Buryła, t. 2: Proza (1), oprac. S. Buryła, Kraków 2004, s. 177. 
lukę - lukę, która powstaje między rosnącą popularnością pisarza w Polsce, sygnowaną kolejnymi publikacjami jego książek ${ }^{27}$ oraz rosnącą liczbą profesjonalnych komentarzy, a rozproszonym, instytucjonalnym buforem polskiej dyskusji wokół jego pisarstwa.

\section{Centro Culturale Primo Levi}

Via SS. Giacomo e Filippo, 31/2C

16121 Genova - I

Tel.: (+39) 0108310748

Faks: (+39) 0108391490

E-mail: info@centroprimolevi.it

Strona internetowa: http://www.centroprimolevi.it/

\section{Centro Internazionale di Studi Primo Levi}

Centro Internazionale di Studi Primo Levi

Via del Carmine, 13 ( $1^{\circ}$ piano -10122 Torino

Tel.: (+39) 0114369940

Faks: (+39) 0114319785

E-mail: info@primolevi.it

Strona internetowa: http://www.primolevi.it/

${ }^{27}$ Nakładem Wydawnictwa Literackiego ukazały się następujące pozycje: P. Levi, Pograżeni i ocaleni, przeł. S. Kasprzysiak, Kraków 2007; idem, Czy to jest człowiek, przeł. H. Wiśniowska, Kraków 2008; idem, Rozejm, przeł. K. Żaboklicki, Kraków 2009. 